\title{
Preferred leadership style, managerial and entrepreneurial inclination among Hungarian students
}

\author{
Éva Perpék ${ }^{1 *} \mathbb{B}$, Ágnes Győri ${ }^{1}$ and György Lengyel ${ }^{2}$
}

\author{
${ }^{*}$ Correspondence: \\ eva.perpek@yahoo.com \\ ${ }^{1}$ Centre for Social \\ Sciences, Eötvös Loránd \\ Research Network, \\ Centre of Excellence \\ of the Hungarian Academy \\ of Sciences, Tóth Kálmán u. 4 \\ Budapest 1097, Hungary \\ Full list of author information \\ is available at the end of the \\ article
}

\begin{abstract}
Although a great deal of research has been done on leadership styles, and university students have often been the subject of exploratory research in social sciences, the Full Range Leadership model has been applied to young people only in a few instances. In this article, the authors seek to survey the preferred leadership styles among Hungarian students and explore how they correlate with managerial and entrepreneurial inclination. A complex analysis of leadership style preferences of university students combined with their managerial and entrepreneurial inclination, social and cultural resources is rare in the research practice so far. The online questionnaire used in the research was completed by 335 university students studying economics, engineering and social studies both in Budapest and in the country. The questionnaire was completed by 335 university students. The results are exploratory and they amend the existing leadership typologies at some points. Based on the results of the Multifactor Leadership Questionnaire featuring 36 self-rating items, four distinct leadership styles emerged within the target group, representing the transformational, the supportive, the defensive, and the laissez-faire leadership types. The multivariate analysis has shown that while managerial inclination is related to the transformational style of leadership, entrepreneurial aspirations are associated with the transformational and supportive leadership styles.
\end{abstract}

Keywords: Leadership style, Transformational leadership, Managerial aspirations, Entrepreneurial inclination, University students

\section{Introduction}

Our paper aims to shed light on the preference of higher education students in terms of leadership styles and explore the factors associated with their leadership aspiration and entrepreneurial inclination. The various leadership styles are investigated by the Full Range Leadership model. Despite the fact that a number of research efforts have been made in the subject of leadership styles (Gregor \& O'Brien, 2016; Sheppard, 2018) and the application of the Full Range Leadership model is also considered to be widespread in international management research, it has rarely been tested on a sample of several hundred aspiring leaders and future participants of the labour market.

(c) The Author(s), 2021. Open Access This article is licensed under a Creative Commons Attribution 4.0 International License, which permits use, sharing, adaptation, distribution and reproduction in any medium or format, as long as you give appropriate credit to the original author(s) and the source, provide a link to the Creative Commons licence, and indicate if changes were made. The images or other third party material in this article are included in the article's Creative Commons licence, unless indicated otherwise in a credit line to the material. If material is not included in the article's Creative Commons licence and your intended use is not permitted by statutory regulation or exceeds the permitted use, you will need to obtain permission directly from the copyright holder. To view a copy of this licence, visit http:// creativecommons.org/licenses/by/4.0/. 
By contrast, the entrepreneurial inclination and activity of the young adult and adult population are far better exploited research areas (Fitzsimmons \& Evans, 2005; Kuczi et al., 1991; Kuczi \& Lengyel, 2001; Lengyel \& Róna-Tas, 1997-1998; Lengyel, 2008, 2009). As far as current international comparative research is concerned, Hungary has been participating in the Global University Entrepreneurial Spirit Students' SurveyGUESSS, an international survey since 2006, and certain analytical aspects of it were used in this study. The value to our research is enhanced by the fact that preferred leadership styles were investigated specifically among young people and mapped in the context of managerial and entrepreneurial inclination.

The present research is a complex analysis of leadership style preferences of university students, combined with their managerial and entrepreneurial inclination, socioeconomic and study backgrounds, social and cultural resources. Besides, using the Multifactor Leadership Questionnaire ${ }^{1}$, the research contributes to the adaptation and modification of the Full Range Leadership model within a specific target group.

The paper will first present the theoretical models of leadership styles based on the relevant literature, then provide an overview of the findings by international and Hungarian research on managerial and entrepreneurial inclination that are relevant to our investigation. This is followed by an overview of the database as well as the variables and the methods applied. In presenting the results, the leadership types will be revealed as well as the identification of the various groups of respondents with these types. The paper will be concluded by elaborating regression models for the various leadership styles and adding some summarising thoughts.

\section{Theoretical and empirical background}

In the late 1930s Kurt Lewin, one of the key figures in the literature on leadership, developed a theory underpinned by experiments which can be implemented in practice. ${ }^{2}$ In his experiments the participants belonging to the group led in democratic manner demonstrated less hostility and aggression than those being part of the group characterised by autocratic leadership. The circumstances of the experiment as well as the democratic and autocratic nature of leadership have since been criticised by many, including Lewin himself. Some further criticism pointed out that the application of the laissez-faire type leadership had initially not been intended, it was only introduced by Lewin as a sort of rhetorical switch to save his experiment and to save the reputation of democracy (Billig, 2015).

Rensis Likert, the other classic author concerning leadership theory elaborated two times two leadership styles in terms of the autocratic-democratic dichotomy: he identified the exploitative-authoritative, the benevolent authoritative, the consultative and the participative styles. The authoritative-exploitative leadership system is hierarchic: the leader exercises tight control over his or her subordinates and spurs them for better performance through intimidation. At the same time, benevolent authoritative leaders combine the above with paternalistic care. In case of consultative leadership, information

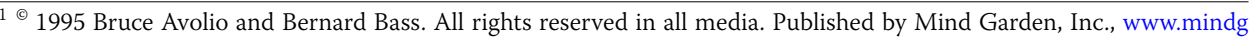
arden.com.

2 Lewin and his students first tested the impact of autocratic and democratic leaders on their subordinates in two maskmaking groups, each composed of 11-year old children, mainly boys. Later the number of groups participating in the experiment was extended to four and the leadership roles were complemented by the laissez-faire style.
} 
flow is multidirectional: although subordinates are consulted with, decisions are taken by the leaders. The basic motivation of subordinates in this scenario is to gain rewards and avoid punishment. The system favoured by Likert is participative leadership. Under this system, subordinates participate in setting goals, in making decisions and thereby are characterised by responsibility and accountability (Likert, 1967).

According to the transactional and transformational model of effective leadership, (political) leadership is more than enforcing obedience (Boda, 2013; Burns, 1978; Bryman, 1996). In Weberian terms, leadership can be interpreted in the domain of legitimate rule. In case of the transactional style of leadership, goals are achieved by implying the possibility of direct gains (sense of achievement, recognition, remuneration) and losses. As a rule, transformational leaders motivate by evoking more abstract tools (common objectives, mission, vision, etc.), hence the moral nature of transformational leadership. Although Burns' leadership theory has also been subject to much criticism, it had a fertilising effect on empirical research.

The emergence of the Full Range Leadership model recognised by management literature and used by can also traced back to the research of Burns (Bass, 1985). In this model the transformational and the transactional leadership approaches were complemented with the laissez-faire style. In the original Full Range Leadership model, the transactional leadership style is made up of contingent reward and active leadership factors based on exceptions/excuses. In rewards achievement/contingent reward, the tasks and goals as well as rewards and punishments associated with low, medium and high performance are clearly set. Transformational leadership means that the leader concerned offers the prospect of transformation and actually transforms his or her subordinates by inspiring them to perform better than they had originally intended to (Stafford, 2010, p. 101). It is important to stress that transactional and transformational leadership types are not necessarily mutually exclusive but are employed side by side and can complement each other (see for instance Avolio et al., 1999). Individual situations will decide which type of leadership behaviour proves to be the most effective. Edwards and Gill (2012) found that while the transformational leadership style was effective at all levels of the hierarchy, the transactional style worked only at lower levels. The laissez-faire leadership type did not prove to be efficient at any of the leadership levels. International research findings show that the organisational units applying the transformational leadership approach prove to be the most efficient (Lowe et al., 1996). On the other hand, Zaal (2017, $N=6$ leaders, 36 employees) insisted in her paper that both the transactional and the transformational leadership styles produced better team results than the autocratic approach. As far as the genders are concerned, she found that while women tend to prefer the transformational leadership type, men tend to advocate transactional leadership.

One of the most commonly used and most reliable instruments to conceptualise and operationalise the Full Range Leadership model is the Multifactor Leadership Questionnaire (Avolio \& Bass, 1990; Avolio et al., 1996). One of the advantages of the questionnaire is that it offers an opportunity to examine leadership styles from several aspects. On the one hand, leaders can provide a self-assessment of his leadership style, which creates an opportunity for self-reflection; on the other hand, subordinates can give an opinion on their leader's leadership style through the same criteria, thus creating an opportunity for feedback. Furthermore, the questionnaire has 
an extended version for team use, while there is another one used for assessing the current and the desired situation. Of the five versions of the Multifactor Leadership Questionnaire (MLQ), the reduced, 36-item scale was used in the present research. The questionnaire is widely applied in research on management, but is also increasingly used among employees working in education, healthcare and public administration. As far as its limitations of MLQ are concerned, some authors point out that leadership styles correlate with one another, which reduces the validity of the tool. Others believe that MLQ exaggerates the role of the leader and neglects such important factors as organisational characteristics, interpersonal relations or the position occupied in the managerial hierarchy (Edwards \& Gill, 2012; Kelloway et al., 2000). Besides, it must be noted that the questionnaire is based on perceptions, and in this sense cannot be regarded as a tool that assesses the efficiency of leadership objectively. Despite the above limitations, MLQ was found to be suitable for testing on a sample of Hungarian students.

The Multifactor Leadership Questionnaire was tested on a small size Hungarian sample by Filep (2018). He had the version of the MLQ comparing desired and actual styles of leadership filled out by the leaders of 23 small businesses in Szabolcs-Szatmár-Bereg County, Hungary. He found that the leaders concerned wished to move mostly towards contingent rewards and idealised influence embodied by transactional and transformational leaders. The author believes that enterprises using the transformational leadership style are more successful to some extent than the others in the sense of realising slightly more return on sales within error margin.

Our own research findings - to be set out in more detail below-suggest that four types of leadership style emerge from the Full Range Leadership model: the transformational, the supportive, the defensive and the laissez-faire types of leadership style. The first type, i.e., the transformational leadership type, has three characteristic features: vision, the ability to build trust and integrity. The second type includes supportive leadership characteristics featuring personalised coaching and intellectual stimulation. The third leadership style of the adapted Full Range Leadership model is the defensive style, which focuses on errors and active correction. In this model the profile of an active, but actively defensive leader emerges. The fourth, i.e., the laissezfaire style, actually refers to the refusal of active leadership, non-intervention, management by exception and ad-hoc problem solving without exploring the reasons and preventing their repeated emergence (Avolio \& Bass, 1995; Bass \& Avolio, 2004; Filep, 2018; Stafford, 2010).

Figure 1 offers an interpretation of the four leadership styles and the Full Range Leadership model as adjusted by us both in the active-passive and in the effectiveineffective leadership dimensions.

The other focus of our research was entrepreneurial potential. Krueger and Brazeal (1994) and Lengyel (2008, p. 429) point out that entrepreneurial inclination should be differentiated from specific entrepreneurial intentions. It is a broader concept and implies a kind of personal openness to grasping business opportunities in principle. Shapero and Sokol (1982) had used the adjectives "resilient" and "self-renewing" to describe the economic environment which benefits potential entrepreneurs. These adjectives are currently considered as buzzwords in a number of other disciplines. 


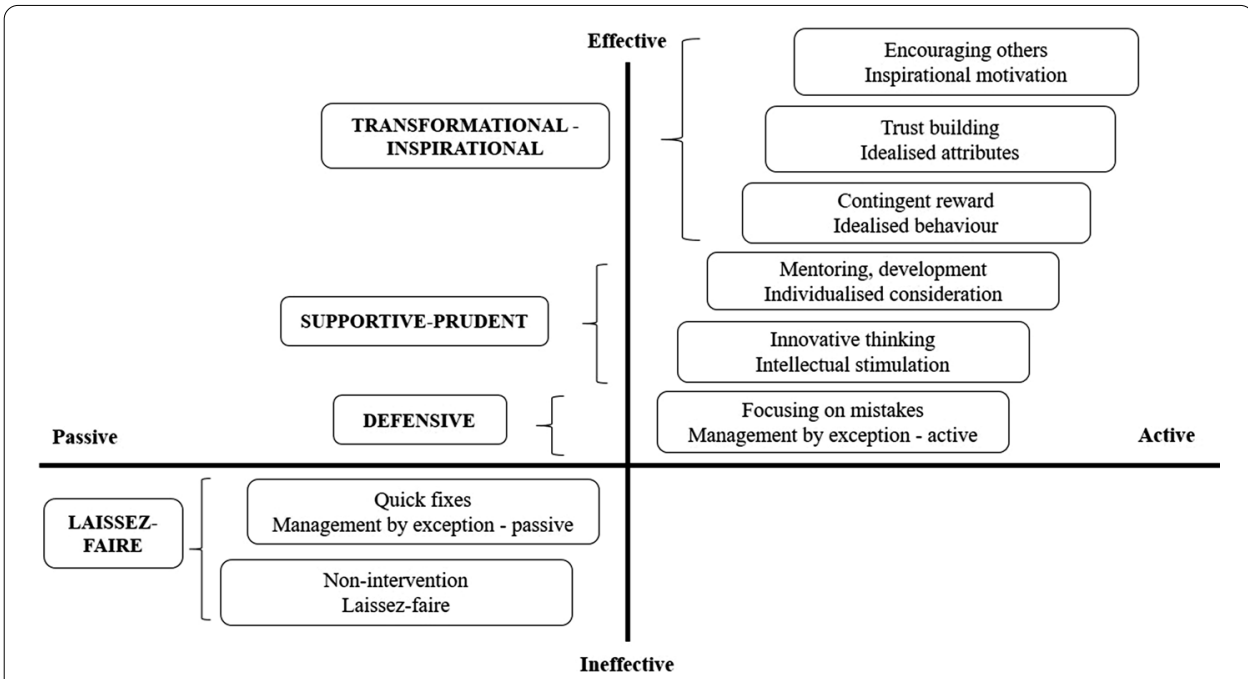

Fig. 1 Full Range Leadership model: adaptation. Source the authors' own compilation based on Avolio and Bass (1995) and Chancy (2017)

Some of the other relevant works focusing on entrepreneurial inclination include the research by Etzioni (1987), Radaev (1997), Fitzsimmons and Evans (2005), as well as Lengyel $(1996,2008)$.

Lengyel's (2008) research regarding entrepreneurial inclination cover the period between 1988 and 2007. His findings reveal that during the nineties, entrepreneurial potential was stronger among men and young people. Social status also showed a positive correlation with entrepreneurial inclination: those considering themselves to belong to the high or the middle classes were more eager to enterprise than those belonging to the low or lower middle classes. The level of education also influenced entrepreneurial inclination to a considerable degree: whereas the notion to start an enterprise was the most popular among those having vocational and secondary technical qualification, the entrepreneurial intentions of higher education graduates only slightly exceeded the average.

A number of researchers have found that entrepreneurial potential is one of the key factors to the success of an enterprise (Hofmeister et al., 2015; Rauch et al., 2009). The combination of this attitude and behaviour shows an overlap with the transformational leadership style in the sense that the leaders concerned are able to convey their own managerial ambitions as well as the organisation's interests to the subordinates, thereby encouraging them to identify themselves with the organisation and to perform to meet the highest standards possible. In line with this reasoning and with international research findings, it can be assumed that there is a significant positive correlation between the transformational leadership style and entrepreneurial inclination.

Hofmeister et al. (2015) conducted a research in 2011 on a sample of two hundred Hungarian micro, small and medium enterprises in the subject of entrepreneurial proclivity and leadership styles. In their interpretation, leaders' entrepreneurial proclivity means pro-activeness, courage to take risks as well as innovative spirit in 
Schumpeterian sense and competitive behaviour. Based on international theories, they differentiated the entrepreneur, and entrepreneurial spirit from small business orientation, the ownership of a small business. Hofmeister and her co-authors found that certain elements of entrepreneurial proclivity were connected to leadership styles. The findings are restricted by the fact that the reliability of the scale adopted from international research practice to assess entrepreneurial proclivity was low. They found positive correlation between innovativeness and both participative and supportive styles of leadership as well as between pro-activeness and the supportive style of leadership. By contrast, they detected negative correlation between risk-taking and both the participative and consultative types of leadership style. Dzomonda et al. (2017, $N=103$ leaders), however, used leadership types to explain entrepreneurial orientation. Both the transactional and the transformational types of leadership correlated with entrepreneurial orientation; the correlation being stronger in the case of transformational leadership. Öncer (2013, $N=171$ employees) found that while the transactional type of leadership correlated positively with entrepreneurial orientation only, the transformational type correlated with all three dimensions of entrepreneurial orientation of innovativeness, risk taking and pro-activeness.

The most extensive international research examining the career choice intentions of youth, including entrepreneurial spirit is the Global University Entrepreneurial Spirit Students' Survey, also known as GUESSS. The project is coordinated by the University of St. Gallen. The survey had been launched in 2003, the Hungarian higher education institutions joined in 2006. A number of analyses based on the 2006, 2008, 2011 and 2016 surveys when Hungary was also involved (Gubik, 2015; Gubik \& Farkas, 2016; ImrehTóth et al., 2013; Koltai \& Szalka, 2013; Petheő, 2013; Reisinger, 2013; Szerb \& Lukovszki, 2013; Temesi, 2014). The 2016 survey was conducted with the participation of over 122 thousand students. According to the recently published GUESSS findings, Hungarian students exhibited lower entrepreneurial intentions after graduation than their foreign counterparts, and preferred to work as employees as opposed to becoming independent. Only about one of every twenty students claimed that they intended to launch their own business after graduation. This proportion is behind both the EU average and that of the Visegrád countries. However, as far as the long-term career plans of Hungarian youth are concerned, the notion of launching a business or working independently after some years of employment is clearly on their minds: around one third of the respondents insisted that starting their own business within 5 years after graduation is part of their career aspirations (Gubik \& Farkas, 2017). Of the works mapping the career aspirations of students, the research of Gregor and O'Brien (2016), and Sheppard (2018) inter alia are considered to be relevant on international level.

\section{Methods}

Research questions, data and sample

The study aims to answer the following research questions. What leadership styles university students identify themselves with in terms of the Full Range Leadership Model (RQ1)? What socio-economic, social, cultural, and academic backgrounds characterise the factors of each leadership style (RQ2)? What correlations can be identified (if any) 
between leadership styles on the one hand, and managerial, entrepreneurial inclination on the other (RQ3).

The analysis is based on processing the database of the online survey questionnaire conducted in 2018 by the SocioLab research group ${ }^{3}$ of the Corvinus University of Budapest. The research explored the preferred leadership styles of students pursuing their studies in the fields of economy, engineering, natural and social sciences, as well as the socio-demographic characteristics and aspirations of the styles concerned. The main objective was to reveal the possible correlations between the potential leadership styles on the one hand and entrepreneurial and managerial aspirations on the other.

When creating the sample, instead of being representative, the main aim was to be able to formulate hypotheses about social characteristics and aspirations. The survey was conducted in October and November 2018. ${ }^{4}$ After data filtering and cleaning, the database contained 335 respondents. ${ }^{5}$ This sample size exceeds most of the surveys referred to above (Dzomonda et al., 2017; Filep, 2018; Hofmeister et al., 2015; Öncer, 2013; Zaal, 2017).

The sample consists of respondents aged 18-24; four fifth of them (82\%) are undergraduate (BA/BSc-) students. As far as the composition of the sample is concerned in terms of gender, the proportion of female respondents was higher ( $60 \%$ female vs. $40 \%$ male). Nearly half of those completing the questionnaire (47.8\%) studied in Central Hungary (in Budapest, in Gödöllö); around one-third of them (36\%) pursued their studies in the Central Transdanubian region (in Dunaújváros, Székesfehérvár, and Veszprém) and nearly one sixth of them (16.1\%) studied at other country universities (Debrecen, Nyíregyháza, Szeged, Pécs). While a large proportion of them (48.6\%) studies in the field of social sciences, one third (33.9\%) of the respondents study engineering and natural sciences, and only $17.4 \%$ take part in economics and other training. As far as their economic-social background is concerned, more than two in five judged the social status of their respective families to be higher than average in this respect, and the about the same proportion of the respondents claimed that the status of their family was average. One in eight said that their social status was worse than average. With regard to subjective appreciation of well-being, a great majority was satisfied with their lives, (three out of five marked the fairly satisfied or the very satisfied option on a five-point scale) and considered themselves to be happy (five out of seven respondents rated their happiness five

\footnotetext{
${ }^{3}$ Besides the authors of the present paper, further members of the research group included Fanni Bársony, Ágnes Czakó, Vera Horváth and Gergely Horzsa.

4 The paper specifically seeks to focus on the leadership style preferences of Hungarian university students. For that reason, we contacted all the major Hungarian higher educational institutions, but not all of them granted the authorisation and assistance needed to access the students through the online questionnaire. We would like to say thank you hereby to the Budapest Metropolitan University, the Corvinus University of Budapest, the Budapest University of Technology and Economics, the Budapest Business School, the University of Debrecen, the University of Dunaújváros, the Eötvös Loránd University, the Eszterházy Károly University, the Károli Gáspár University of the Reformed Church, the Óbuda University, the University of Pannonia, the University of Pécs and the University of Szeged for their co-operation as well as to their students for undertaking to take part in the survey.

5 At the time of the survey, approximately two hundred thousand students pursued their studies in sixty-four institutions of higher education in Hungary. The target population of our research included full-time students in faculties of engineering, social sciences, sciences and economics at major Hungarian universities. The target population, interpreted by the majors involved in the research, consists of 26,291 respondents (Office of Education, 2017/18 academic year). Presuming a hypothetic complete inquiry, approximately one of every seventy-seven students, i.e. $1.3 \%$ completed the questionnaire. The extent of the difference in the distribution of the population and the distribution of the sample is between 6.4 and 3.2 percentage points, depending on the field of study. Students of engineering, science and economics are slightly under-represented in the sample; as well as undergraduate students in terms of the level of education. The data are not representative; the correlations revealed are valid for the sample.
} 
or higher on a seven-point scale). Analysing the sample in terms of cultural and social resources, it reveals that the majority is characterised by proficiency in two foreign languages (half of the respondents speak two, one third of them up to one, and one sixth of them are proficient in three or more foreign languages); the average number of friends is $^{6} 9$, more than two-thirds of them discusses political issues with their acquaintances and friends on a regular basis. As far as their generalized level of trust is concerned, 51\% of them think that people can always or nearly always be trusted.

\section{Variables and research design}

Out of the five versions of the Multifactor Leadership Questionnaire (Avolio \& Bass, 1990; Avolio et al., 1996) used in international research practice to measure identification with the various leadership styles, a shorter, self-evaluating version was used for the purpose of the present research. Respondents could express the degree of their agreement through a five-point Likert scale, which measures young people's behaviour as leaders, their managerial and decision-making behaviour in 36 imaginary situations. ${ }^{7}$

In addition, the questionnaire contains information about the responding students' managerial and entrepreneurial inclination, entrepreneurial plans, and also examined their future plans about launching and financing a business. To map leadership types preferred by young people, the latent structures behind statements were examined with principal component analysis on a 36-item scale used in the questionnaire. Factor analysis identified four distinct factors. The fundamental question was how preferred leadership style elements correlate with the respondents' personal managerial and entrepreneurial inclination in case they are controlled for socio-demographic, cultural and social background. The structure of the research is summarised in Fig. 2.

\section{Research findings}

\section{Leadership styles and preference by groups of various socio-demographic, social} and cultural backgrounds

The first research question was aimed at finding out what leadership styles university students identify themselves with (RQ1). Factor analysis to measure identification with leadership styles revealed four factors on a scale consisting of 36 statements (principal component analysis, rotation method: varimax) (Table 1). The value of the KaiserMeyer-Olkin criterion was $0.84\left(\chi^{2}: 3158.05\right.$; Sig: 0.000). The factors retained $47 \%$ of the set of information of the original variables measured. ${ }^{8}$

The first factor includes variables stressing inspirational motivation, encouragement to make efforts and to enhance productivity, a collective sense of mission, the attainment

\footnotetext{
${ }^{6}$ In order to eliminate the distorting effect of exceptionally high values, 25 friends were reckoned with in case respondents said that they had more than 25 friends.

7 The actual question featured in the questionnaire was: Imagine that you have become a manager and as a manager you oversee people and take decisions. Judge how frequently each statement would fit your management style. Use the following rating scale: $0-$ Not at all, 1 -Once in a while, 2-Sometimes, 3-Fairly often, 4-Frequently, if not always. It is to be noted that during the analysis, the coding was transformed to a $1-5$ scale to facilitate interpretation. The survey was anonymous. The survey was conducted in line with the research ethics policy of the Corvinus University of Budapest. The respondents had been informed about features, data protection and ethical considerations of the research.

${ }^{8}$ As the fit indices of the three-factor theoretical model did not prove to be suitable, instead of discarding certain items, alternative models were tested. We sought to use the four-factor structure on the basis of results obtained from differently structured models. Owing to the four-factor structure, less information is lost, the four factors preserve a higher percentage $(48 \%)$ of the heterogeneity of the original variables than three factors would $(32 \%)$.
} 


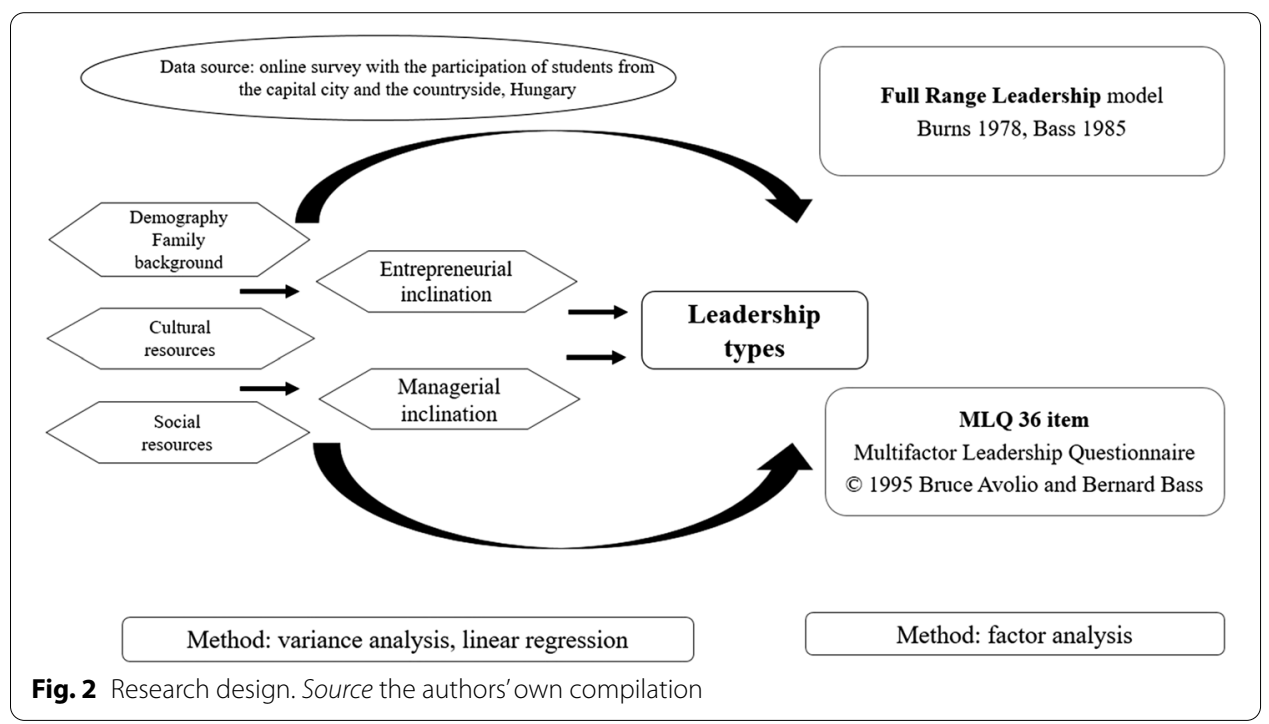

of joint goals as well as variables representing interests. As this factor bear the stylistic elements of the transformational leadership model as defined in literature, it is called transformational or more broadly, to reflect the nature of the items involved, transformational-inspirational factor.

As far as the variables belonging to the second factor are concerned, they include recognising and developing individual abilities, personalising tasks, individual mentoring and attention, as well as individual effort and rewarding subordinates for achieving the goals. This factor represents a specific segment of what is defined as the transactional type in literature, where the focus is on supporting the subordinates, paying attention to the individual and taking several perspectives into account. Based on the peculiar features of its elements, this type is called supportive, or more broadly "supportive-prudent" factor in the present paper. It is evident from Table 1 that there is an overlap between the transformational and the supportive factors in the case of three items conveying trust and transparency. Thus, these characteristics prevail in both leadership styles.

Based on the variables included in the third factor a "defensive" type emerge, whose highlighted stylistic elements include keeping track of errors and failures as well as complying with rules and regulations. This factor shows a partial overlap with the transactional type described in literature, but only includes the negative-restrictive elements of the latter and lacks the positive ones. Besides, one of the items show overlap with the laissez-faire style. ${ }^{9}$

Finally, the fourth factor clearly encompasses the elements of the typology of the "laissez-faire" model as described in literature: the leader observes workplace events with minimal interest, seeks to stay away from decision-making and intervenes only when it becomes inevitable to do so.

\footnotetext{
${ }^{9}$ It is important to note that the error-focused defensive style is clearly distinct from the others in each of the three-, four- and five-factor models, therefore it is appropriate to feature it as a type separate from the transactional style, unlike in the Full Range Leadership models.
} 
Table 1 Results of the factor analysis of variables measuring identification with leadership styles (factor weights)

\begin{tabular}{|c|c|c|c|c|}
\hline \multirow[t]{2}{*}{ Rotated factor matrix } & \multicolumn{4}{|c|}{ Component } \\
\hline & 1 st factor & 2nd factor & 3rd factor & 4th factor \\
\hline Compelling future & 0.698 & 0.191 & -0.039 & -0.128 \\
\hline Sense of purpose & 0.657 & 0.174 & 0.107 & -0.054 \\
\hline Power and confidence & 0.616 & -0.157 & 0.250 & -0.231 \\
\hline Optimistic future & 0.585 & 0.204 & -0.205 & -0.036 \\
\hline Enthusiasm & 0.584 & 0.228 & 0.009 & -0.196 \\
\hline Goal achievement & 0.578 & 0.388 & -0.060 & -0.011 \\
\hline Respect & 0.561 & 0.134 & 0.173 & -0.190 \\
\hline Pride & 0.534 & 0.017 & 0.098 & -0.064 \\
\hline Collective mission & 0.525 & 0.228 & -0.017 & 0.111 \\
\hline Expectation & 0.365 & 0.361 & 0.181 & -0.228 \\
\hline Responsibility & 0.334 & -0.029 & 0.218 & -0.222 \\
\hline Values and beliefs & 0.322 & 0.254 & 0.081 & 0.002 \\
\hline Satisfaction & 0.278 & 0.265 & 0.001 & -0.205 \\
\hline Different angles & -0.003 & 0.659 & 0.074 & -0.021 \\
\hline Individual needs & -0.018 & 0.628 & -0.001 & -0.069 \\
\hline Strengths development & 0.306 & 0.569 & -0.019 & -0.240 \\
\hline New ways & 0.219 & 0.475 & 0.081 & -0.043 \\
\hline Moral consequences & 0.312 & 0.472 & -0.058 & 0.069 \\
\hline Re-examination & 0.011 & 0.450 & 0.097 & -0.046 \\
\hline Group interest & 0.279 & 0.431 & 0.000 & -0.033 \\
\hline Various perspectives & 0.225 & 0.418 & -0.072 & -0.136 \\
\hline Assistance & 0.122 & 0.396 & -0.110 & -0.146 \\
\hline Individual treatment & 0.123 & 0.394 & 0.156 & -0.128 \\
\hline Teaching and coaching & 0.278 & 0.389 & 0.181 & -0.228 \\
\hline Complaints & -0.092 & 0.050 & 0.667 & 0.199 \\
\hline Mistakes & 0.166 & -0.062 & 0.664 & -0.022 \\
\hline Failures & 0.174 & 0.140 & 0.607 & -0.106 \\
\hline Exceptions & 0.044 & -0.029 & 0.560 & 0.227 \\
\hline No breaking, no fixing & -0.024 & 0.115 & 0.302 & 0.178 \\
\hline Wait and see & -0.057 & -0.235 & 0.032 & 0.663 \\
\hline Chronic action & -0.041 & -0.052 & 0.140 & 0.653 \\
\hline Involvement avoidance & -0.140 & -0.091 & 0.099 & 0.642 \\
\hline Decision avoidance & -0.172 & -0.089 & 0.000 & 0.630 \\
\hline Delayed response & -0.008 & -0.213 & -0.077 & 0.645 \\
\hline Absence & -0.174 & -0.226 & 0.101 & 0.540 \\
\hline Serious intervention & -0.031 & 0.055 & 0.074 & 0.529 \\
\hline
\end{tabular}

Extraction method: principal component analysis. Rotation method: Varimax with Kaiser normalisation

Source: the authors' own compilation

* Remark rotation after seven iterations

The next stage of the research process was focusing on how far the responding students are characterised by each of the four leadership style factors (RQ2). The demographic, social and cultural background of each of the factors was investigated through one-way variance analysis (using $p<0.1$ significance level). For each of the analysed dimensions, the detailed results, the mean values of the factors and their standard 


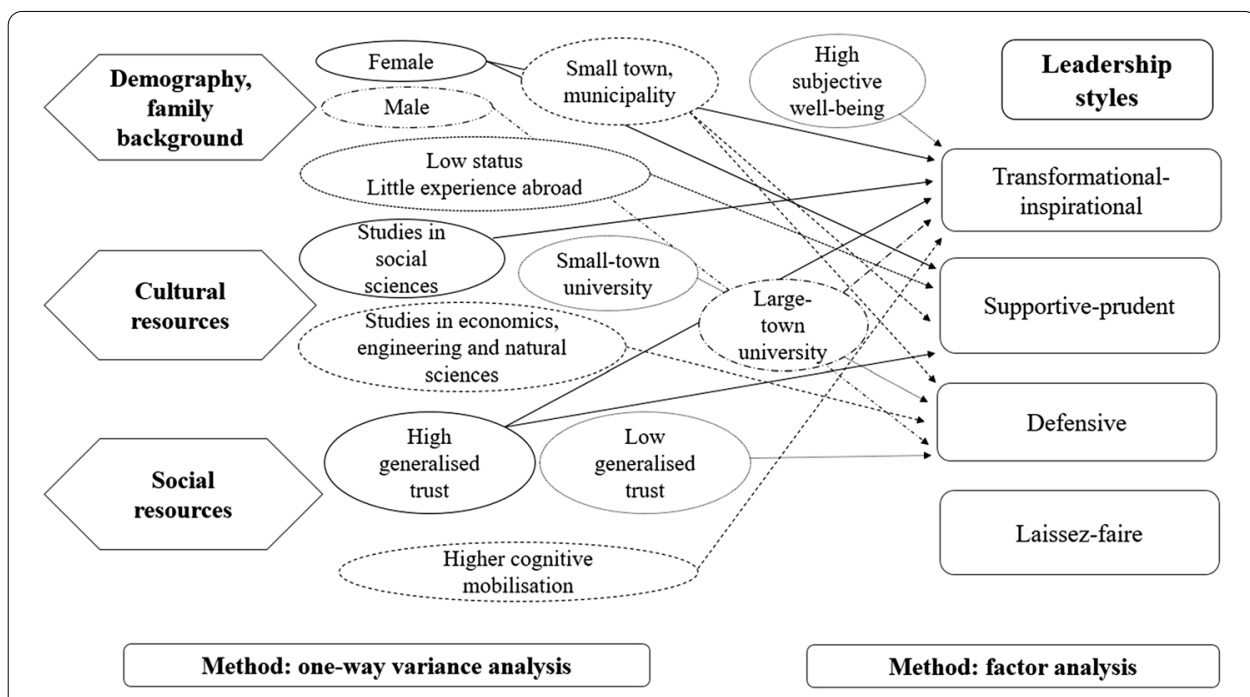

Fig. 3 Correlations of background variables and managerial types. Source the authors' own compilation

deviation are included in Table 1 of the Appendix. Based on the results, the following findings can be established (Fig. 3).

There is significant difference between genders in terms of three factors: identifying themselves with the supportive and transformational styles is more characteristic of female students, while the preference of the defensive style is more typical of males. As far as the settlement type of the place of birth is concerned, it was found that whereas supportive and defensive leadership styles were relatively more characterising those born in small towns and municipalities, they were much less characteristic of those born in the capital. With regard to the subjective indicators used for measuring the social and financial background of the family, the groups differed significantly in terms of only a sole factor, namely, that the supportive style of leadership was significantly more characteristic of students who came from a family with lower social and financial status, that is in the case of students who rated the social position of their family worse than average as well as of those who had been abroad less frequently in the preceding 5 years than the average. As for subjective well-being, the preference for the transformational style of leadership is significantly more characteristic of those being satisfied with their lives. As far as the various dimensions of the social resources are concerned, a higher level of cognitive mobilisation, that is having discussions about public and political affairs with friends and acquaintances frequently, correlated positively with the acceptance of the transformational leadership style (the other factors did not show any significant difference among the groups). In terms of generalised trust, a further variable used for measuring social resources in the questionnaire, it can be inferred that a higher degree of trust correlates positively with the preference of both the supportive and the transformational styles of leadership. By contrast, a lower degree of trust correlates positively with the acceptance of the defensive-style factor. Further significant differences have emerged with regard to group averages in terms of the type and location of higher education studies: while preference for the transformational leadership style factor is relatively more common among students pursuing their studies in the field of social sciences, the defensive style is more 
favoured among students involved in the field of economic and natural sciences, as well as engineering. With regard to the location of study, whereas students studying in the capital and in bigger cities (Szeged, Debrecen, Miskolc, Pécs) seem to prefer the transformational style of leadership, identification with the defensive style of leadership is significantly more characteristic of those studying at smaller universities in the country. The other background variables such as foreign language proficiency used to measure cultural resources, subjective social mobility, participation in financial-entrepreneurial courses and the training level of higher education studies did not reveal any statistically significant differences.

\section{Leadership styles, managerial and entrepreneurial inclination}

The third research question related to the possible correlation between leadership styles on the one hand, and managerial, entrepreneurial aspirations on the other (RQ3). Based on the relevant literature, it was assumed (Hofmeister et al., 2015) that the preference for transformational and supportive leadership styles correlates with entrepreneurial inclination. To answer the question, multivariance models were examined. It should be pointed out that the present research is of exploratory nature: it is primarily aiming at exploring the relationship between identification with the various leadership styles on one hand and having managerial, entrepreneurial inclination on the other.

The dependent variables used in the analysis are the factors embodying the various elements characterising each style, as described in the previous chapter. As they are continuous variables, the analysis was carried out by means of linear regression models using ordinary least squares (OLS). ${ }^{10}$ Besides managerial and entrepreneurial inclination (1), the explanatory variables in the model included (2) the variables of demographic and family background, (3) the indicators of social resources and (4) cultural resources (the characteristics of the training).

(1) Dichotomous variables were used to measure MANAGERIAL AND ENTREPRENEURIAL INCLINATION ( 1 , if he/she would be pleased to be a leader and 0 , if not or "it depends"; 1 , if he/she would be pleased to become an entrepreneur and 0 , if not or "it depends". It was found that 47.2 and $47.8 \%$ of the students constituting the sample would be pleased to be managers and entrepreneurs, respectively. Albeit the rates are close to one another and there is an obvious link between the two roles, managerial and entrepreneurial inclinations do not coincide. Only $57.6 \%$ of those demonstrating managerial inclination would like to be entrepreneurs at the same time. (2) Respondents' coding by GENDER was as follows: female students were coded 1 , and male were coded 0 . The social background of the family was described based on the students' own categorisation (SUbjective Social Position) and the original continuous variables were used for the purpose of the analysis: the respondents were asked to rate their family on the social ladder using a 10-point scale (the lowest social status was marked with 1, the highest with 10). (3) Access to social resources was approached from two directions: from the aspect of generalised trust on the one hand and from cognitive mobilisation capacities (Inglehart, 1970) on the other-both being included in the model as dichotomous variables.

${ }^{10}$ OLS regression assumes linear relationship between the dependent and independent variables; this relationship is defined by a linear function fitted on the expected values of the dependent variable (Mészáros, 2011). 
The GENERALISED TRUST variable measures whether people can always or generally be trusted (the generalised trust level of $50.7 \%$ of the students constituting the sample was high, that is they deemed that people could nearly always or usually be trusted), cognitive mobilisation was measured through the frequency of having conversations with friends and acquaintances on politics $(70.4 \%$ of the students in the sample discussed public affairs with their friends and acquaintances frequently).

(4) Three dichotomous variables were applied in the analysis to identify the field of training: ECONOMIC SCIENCE, SOCIAL SCIENCE, ENGINEERING AND NATURAL SCIENCE. ${ }^{11}$ Approximately one-sixth (17.4\%) of the students in the sample studied in the field of economics, almost half (48.6\%-a) pursued their studies in the field of social science and one third (33.9\%) in the field of engineering or natural sciences. Finally, a dichotomous variable measuring the location of the university was also included in the model as STUDY LOCATION, which indicates whether the responding student studies in a big city (three in five students in the sample studied in the capital city or another big city such as Szeged, Debrecen, Miskolc, Pécs-and two in five students studied in smaller towns in the country).

It must be noted that several explanatory variables were not included in the model due to the lack of their significant impact. The settlement type of the place of birth, the subjective financial situation, the indicators of well-being and cultural resources (number of foreign languages spoken, experience gain in abroad) have do not play important role when trying to explain the preference for any of the leadership styles under review when controlled for the other explanatory variables.

During the regression analysis, first the impact of each of the managerial [model specifications (1) (4) (7) (10)] and entrepreneurial inclinations [model specifications (2) (5) (8) (11)] was examined individually, then models including both aspirations were devised [model specifications (3) (6) (9) (12)]. Estimation results are summarised in Tables 2 and $3{ }^{12}$ The control variables are included in each model.

Although each model is significant, their explanatory power is very different: the greatest proportion of the variables involved is explained in the case of preferring transformational-inspirational leadership style.

Out of the four factors under review, three showed significant correlation with managerial inclination: eliminating the impact of other variables previously involved, MANAGERIAL INCLINATION shows positive correlation with a preference for the transformational leadership style and negative with the acceptance of the defensive and laissez-faire leadership approach.

With regard to the impact of ENTREPRENEURIAL INCLINATION, it is apparent that students who have the inclination to become entrepreneurs, tend to identify themselves with the transformational and the supportive leadership styles. Entrepreneurial

\footnotetext{
${ }^{11}$ From the nominal measurement level variables related to the FIELD OF STUDY three dummy variables were incorporated into the regression models. The independent variable with the largest standard deviation was omitted from the regression analysis due to multicollinearity: in our case the variable of the academic field of social sciences was not included in the model.

12 The conditions for linear regression were checked for each model. The scatter diagram shows that standardised residuals are uncorrelated and show normal distribution in each model, moreover the significance level of KolmogorovSmirnov test also confirmed the normal distribution of errors (The Kolmogorov-Smirnov significance level was between 0.227 and 0.548 , that is, greater than 0.05 in each case); additionally, VIF values indicated in all cases the absence of multicollinearity (VIF $<2$ and tolerance $>0.5$ ).
} 
Table 2 Correlation between the acceptance of transformational-inspirational and supportiveprudent leadership styles and managerial/entrepreneurial inclination-results of the linear regression models (standardised beta coefficients), 2018, N=335

\begin{tabular}{|c|c|c|c|c|c|c|}
\hline & \multicolumn{3}{|c|}{ Transformational-inspirational } & \multicolumn{3}{|c|}{ Supportive-prudent } \\
\hline & (1) & $(2)$ & (3) & (4) & (5) & (6) \\
\hline Managerial inclination & $0.323^{* * *}$ & & $0.312^{* * *}$ & -0.015 & & -0.032 \\
\hline Entrepreneurial inclination & & $0.115^{* *}$ & 0.057 & & 0.086 & $0.092^{*}$ \\
\hline Gender & $0.112^{* *}$ & 0.081 & $0.119^{* *}$ & $0.136^{* *}$ & $0.152^{* *}$ & $0.0148^{* *}$ \\
\hline SUBJECTIVE SOCIAL POSITION & 0.018 & 0.039 & 0.017 & $-0.175^{* * *}$ & $-0.178^{* * *}$ & $-0.176^{* * *}$ \\
\hline GENERALISED TRUST & $0.116^{* *}$ & $0.159^{* * *}$ & $0.121 * *$ & $0.126^{* *}$ & $0.131^{* *}$ & $0.134^{* *}$ \\
\hline COGNITIVE MOBILISATION & $0.132^{* * *}$ & $0.154^{* * *}$ & $0.131^{* * *}$ & 0.012 & 0.008 & 0.011 \\
\hline ECONOMIC SCIENCES & -0.030 & -0.045 & -0.036 & 0.052 & 0.044 & 0.043 \\
\hline ENGINEERING AND NAT. SCI & -0.102 & $-0.144^{* *}$ & -0.105 & 0.005 & 0.005 & 0.001 \\
\hline STUDY LOCATION & 0.062 & -0.006 & 0.054 & -0.037 & -0.043 & -0.049 \\
\hline Sig. & 0.000 & 0.000 & 000.0 & 0.008 & 0.003 & 0.005 \\
\hline Corrected $R^{2}$ & 0.16 & 0.08 & 0.16 & 0.06 & 0.05 & 0.07 \\
\hline
\end{tabular}

Reference group: would not aspire to be a manager; would not intend to be an entrepreneur; male; one can never or as a rule cannot be cautious enough when it comes to others; never or rarely discusses public affairs with acquaintances, friends; studies in the field of social sciences; university studies at a smaller countryside university

Source: the authors' own compilation

${ }^{* * *} p<0.01 ;{ }^{* *} p<0.05 ;{ }^{*} p<0.1$

Table 3 Correlation between the acceptance of defensive and laissez-faire leadership styles with managerial/entrepreneurial inclination - results of the linear regression models (standardised betacoefficients), 2018, $N=335$

\begin{tabular}{|c|c|c|c|c|c|c|}
\hline & \multicolumn{3}{|l|}{ Defensive } & \multicolumn{3}{|c|}{ Laissez-faire } \\
\hline & (7) & (8) & (9) & $(10)$ & (11) & $(12)$ \\
\hline Managerial inclination & $-0.109^{* *}$ & & $-0.115^{* *}$ & $-0.205^{* * *}$ & & $-0.192^{* * *}$ \\
\hline Entrepreneurial inclination & & -0.060 & -0.080 & & $-0.107^{*}$ & -0.071 \\
\hline Gender & -0.084 & $-0.107^{*}$ & $-0.094^{*}$ & $-0.110^{*}$ & -0.096 & $-0.120^{* *}$ \\
\hline SUBJECTIVE SOCIAL POSITION & 0.007 & 0.015 & 0.008 & 0.025 & 0.013 & 0.026 \\
\hline GENERALISED TRUST & $-0.167^{* * *}$ & $-0.160^{* * *}$ & $-0.164^{* * *}$ & 0.052 & 0.025 & 0.045 \\
\hline COGNITIVE MOBILISATION & -0.026 & -0.017 & -0.024 & 0.082 & 0.068 & 0.083 \\
\hline ECONOMIC SCIENCE & 0.100 & $0.105^{*}$ & $0.108^{*}$ & 0.073 & 0.086 & 0.080 \\
\hline ENGINEERING AND NATURAL SCIENCES & 0.031 & 0.021 & 0.034 & -0.002 & 0.025 & 0.001 \\
\hline STUDY LOCATION & -0.088 & -0.098 & -0.077 & 0.079 & $0.127^{*}$ & 0.089 \\
\hline Sig. & 0.001 & 0.002 & 0.001 & 0.010 & 0.089 & 0.010 \\
\hline Corrected $R^{2}$ & 0.05 & 0.05 & 0.08 & 0.03 & 0.03 & 0.04 \\
\hline
\end{tabular}

Reference group: would rather not be a manager; would rather not be an entrepreneur; male; one can never or as a rule cannot be cautious enough when it comes to others; never or rarely discusses public affairs with acquaintances, friends; studies in the field of social sciences; university studies at a smaller countryside university

Source: the authors' own compilation

${ }^{* * *} p<0.01 ;{ }^{* *} p<0.05 ;{ }^{*} p<0.1$

inclination, therefore, show correlation with the transformational style of leadership and with the component of the transactional type that contains positive elements, which is referred to as the supportive-prudent style. 
The respondents' GENDER has proven to be significant for all four factors: while women identify themselves with the transformational-inspirational and the supportiveprudent leadership styles, man tend to identify themselves with defensive and passive leadership. Concerning the impact of the SUbjective social position used to measure the social background of the respondents, correlation was significant for only one factor: those with a lower social status are more likely to prefer the supportive-prudent leadership style.

The impact of social resources on the acceptance of the various leadership styles was examined in several dimensions. The GENERALISED TRUST variable revealed that a high trust level has a positive effect on the acceptance of both the transformational-inspirational and the supportive-prudent styles of leadership. At the same time, it correlates negatively with defensive leadership. The impact of COGNitive MOBILISATION, the other indicator applied to measure social capital, has shown that those discussing public affairs with their friends and acquaintances frequently prefer transformational-inspirational leadership as opposed to their fellow students who never or only seldom talk about political issues with their friends.

Finally, as far as the impact of the field of training is concerned, the FIELD OF ECONOMICS has a positive effect on accepting the defensive leadership style. The location of the university has no significant effect in complete models. Nonetheless, in models of entrepreneurial aspirations there is only one significant correlation: as opposed to their fellow students studying in smaller towns, students pursuing their studies at universities in the capital and big cities tend to identify themselves with laissez-faire leadership style. However, if the model includes the "managerial inclination" variable, the coefficient concerned is not significant.

\section{Conclusion}

The purpose of the present study was to use the database of a 2018 online survey to first identify the leadership styles Hungarian students prefer, and then explore the characteristics of the relevant leadership style factors in different demographic, cultural and social contexts. The bivariate analyses were followed by multivariate regression analysis to establish correlations between leadership styles and entrepreneurial inclination.

Thus, applying 36 self-rating items of the Multifactor Leadership Questionnaire, the Full Range Leadership model was tested and adjusted. The analysis of the correlations between potential leadership styles and entrepreneurial inclination provides a further added value. The underlying assumption of our study had been that the acceptance of effective leadership styles, called transformational and transactional styles in the original Full Range Leadership model, was correlated with entrepreneurial inclination.

Based on the results of the sample surveyed, it can be assumed that four distinct leadership style factors emerge among university students. The first one, the transformationalinspirational factor embodies a leadership culture encouraging productivity and is based on integrity. The second factor includes leadership tools and approaches focusing on the careful consideration of various perspectives, the support and individual attention of subordinates, wherefore it was coined the supportive-prudent factor. The third factor describes defensive type of leaders and contains elements focusing on the track record of mistakes and failures as well as the compliance with standards. Finally, the fourth factor, 
the laissez-faire style captures passive, non-interfering type of leaders who stay away from taking decision or addressing urgent issues. The findings reveal that the acceptance of a particular leadership style showed some differences in terms of the gender, the social background, the access to social resources and the location of studies of the youth involved in the survey. The transformational style of leadership tends to be more preferred among women and students with high social resources (that is, students with a high level of trust and students discussing public affairs with their friends frequently), as well as among students studying at universities located in big cities. Identification with the supportive leadership style is also characteristic of women and students with a high level of trust but is significantly more preferred among students with a lower social status and among students with a certain level of financial disadvantage. As far as the defensive style of leadership is concerned, it is accepted among students coming from small towns or municipalities who have a low level of trust and students studying economics at smaller universities in the country. The research explored the correlations between leadership styles preferred by young people and entrepreneurial, managerial aspirations.

Multivariate regression analysis was used to address to the main research question regarding the correlations between leadership styles and managerial/entrepreneurial inclination. It was shown that there is a significant relationship between transformational leadership style and both managerial inclination and entrepreneurial aspirations (in separate models), however, if their combine effect is reviewed, the dominant variable would be managerial inclination, whereas entrepreneurial aspiration becomes insignificant. At the same time, supportive leadership style is clearly related to entrepreneurial aspirations. According to the above research results, it can be assumed that while future managers tend to prefer the elements of the transformational leadership style, potential entrepreneurs opt for both transformational and supportive leadership styles.

\section{Appendix}

Table 1 of the Appendix Socio-demographic and cultural background of leadership style factors (one-way variance analysis, mean value and standard deviation of factors), 2018, $N=335$

\begin{tabular}{lllll}
\hline & $\begin{array}{l}\text { 1st factor } \\
\text { Transformational- } \\
\text { inspirational }\end{array}$ & $\begin{array}{l}\text { 2nd factor } \\
\text { Supportive-prudent }\end{array}$ & $\begin{array}{l}\text { 3rd factor } \\
\text { Defensive }\end{array}$ & $\begin{array}{l}\text { 4th factor } \\
\text { Laissez-faire }\end{array}$ \\
\hline $\begin{array}{llll}\text { Gender } \\
\text { Male }\end{array}$ & $-0.152(1.09)$ & $-0.144(1.09)$ & $0.160(0.92)$ & $0.057(1.01)$ \\
Female & $0.101(0.92)$ & $0.087(0.92)$ & $-0.106(1.03)$ & $-0.043(0.99)$ \\
Sig. & 0.023 & 0.023 & 0.017 & NS \\
Settlement type of place of origin & & & & \\
Budapest & $-0.020(1.01)$ & $-0.116(1.07)$ & $-0.106(1.04)$ & $-0.043(1.03)$ \\
Other city, county centre & $0.005(0.90)$ & $-0.002(1.04)$ & $-0.035(0.94)$ & $-0.043(0.98)$ \\
Small town or village & $-0.012(1.11)$ & $0.114(0.84)$ & $0.154(1.03)$ & $0.103(0.99)$ \\
Sig. & NS & 0,078 & 0,068 & $N S$ \\
Subjective social position & & & & \\
Low social status (at most 4 points) & $-0.071(1.19)$ & $0.222(0.95)$ & $0.215(0.90)$ & $-0.057(0.83)$ \\
\hline
\end{tabular}




\begin{tabular}{|c|c|c|c|c|}
\hline & $\begin{array}{l}\text { 1st factor } \\
\text { Transformational- } \\
\text { inspirational }\end{array}$ & $\begin{array}{l}\text { 2nd factor } \\
\text { Supportive-prudent }\end{array}$ & $\begin{array}{l}\text { 3rd factor } \\
\text { Defensive }\end{array}$ & $\begin{array}{l}\text { 4th factor } \\
\text { Laissez-faire }\end{array}$ \\
\hline Average social status (5-6 points) & $-0.063(0.97)$ & $0.065(0.92)$ & $-0.008(0.96)$ & $0.001(1.03)$ \\
\hline $\begin{array}{l}\text { High social status (at least } 7 \\
\text { points) }\end{array}$ & $0.071(0.96)$ & $-0.114(1.06)$ & $0.050(1.05)$ & $0.014(1.01)$ \\
\hline Sig. & NS & 0.091 & NS & NS \\
\hline \multicolumn{5}{|l|}{ Subjective financial situation } \\
\hline $\begin{array}{l}\text { Average or below average number } \\
\text { of trips abroad }\end{array}$ & $-0.052(1.03)$ & $0.086(1.01)$ & $0.045(0.99)$ & $-0.035(1.00)$ \\
\hline $\begin{array}{l}\text { Above average number of trips } \\
\text { abroad }\end{array}$ & $0.120(0.92)$ & $-0.198(0.94)$ & $-0.104(1.03)$ & $0.082(0.98)$ \\
\hline Sig. & NS & 0.016 & NS & NS \\
\hline \multicolumn{5}{|l|}{ Subjective well-being } \\
\hline $\begin{array}{l}\text { Is very or rather unsatisfied with } \\
\text { his/her life }\end{array}$ & $-0.250(1.08)$ & $-0.040(1.09)$ & $0.049(0.93)$ & $-0.061(0.96)$ \\
\hline $\begin{array}{l}\text { Is satisfied or fairly satisfied with } \\
\text { his/her life }\end{array}$ & $0.149(0.91)$ & $0.024(0.93)$ & $-0.029(1.03)$ & $0.036(1.01)$ \\
\hline Sig. & 0.000 & NS & NS & NS \\
\hline \multicolumn{5}{|l|}{ Cognitive mobilisation } \\
\hline $\begin{array}{l}\text { Never or rarely discusses public } \\
\text { affairs with acquaintances, friends }\end{array}$ & $-0.267(1.21)$ & $-0.012(0.90)$ & $0.067(1.04)$ & $-0.110(0.96)$ \\
\hline $\begin{array}{l}\text { Often discusses public affairs with } \\
\text { acquaintances, friends }\end{array}$ & $0.114(0.87)$ & $0.005(1.04)$ & $-0.021(0.97)$ & $0.052(1.01)$ \\
\hline Sig. & 0.001 & NS & NS & NS \\
\hline \multicolumn{5}{|l|}{ Generalised trust } \\
\hline $\begin{array}{l}\text { One can never or as a rule cannot } \\
\text { be cautious enough when it } \\
\text { comes to others }\end{array}$ & $-0.139(1.02)$ & $-0.112(1.03)$ & $0.170(0.94)$ & $-0.036(0.96)$ \\
\hline $\begin{array}{l}\text { People can almost always or } \\
\text { generally be trusted }\end{array}$ & $0.134(0.95)$ & $0.109(0.95)$ & $-0.165(1.02)$ & $0.035(1.03)$ \\
\hline Sig. & 0.012 & 0.042 & 0.002 & NS \\
\hline \multicolumn{5}{|l|}{ Field of higher education studies } \\
\hline Social sciences & $0.170(0.88)$ & $-0.052(0.99)$ & $-0.152(1.03)$ & $-0.012(0.99)$ \\
\hline Engineering-, natural sciences & $-0.231(1.08)$ & $-0.006(1.05)$ & $0.094(1.03)$ & $-0.012(0.99)$ \\
\hline Economic sciences & $0.012(1.04)$ & $0.138(0.90)$ & $0.258(0.80)$ & $0.097(1.12)$ \\
\hline Sig & 0.004 & NS & 0.013 & NS \\
\hline \multicolumn{5}{|c|}{ Location of higher education studies } \\
\hline $\begin{array}{l}\text { Big city: Budapest, Szeged, Debre- } \\
\text { cen, Miskolc, Pécs }\end{array}$ & $0.102(0.93)$ & $-0.032(1.03)$ & $-0.148(1.03)$ & $0.056(1.03)$ \\
\hline Other study location & $-0.135(1.06)$ & $0.042(0.95)$ & $0.196(0.91)$ & $-0.075(0.95)$ \\
\hline Sig. & 0.031 & NS & 0.002 & NS \\
\hline
\end{tabular}

Significance level: $\mathrm{p}<0.1$. NS: $\mathrm{p}>=0,1$

Source: the authors' own compilation

Abbreviations

MLQ: Multifactor Leadership Questionnaire.

Acknowledgements

The authors would like to say thank you for the unnamed reviewer of the Journal of Innovation and Entrepreneurship for his or her useful and inspiring comments and suggestions.

\section{Authors' contributions}

All authors read and approved the final manuscript.

\section{Funding}

This research was subsidised by the 2020 Széchenyi programme of the European Union project entitled "Institutional developments for intelligent specialisation at the Székesfehérvár Campus of the Corvinus University of Budapest" (Grant Number EFOP-3.6.1-16-2016-00013). The authors would like to express their appreciation for the contribution of the project to the research. 
Availability of data and materials

Data sources might be available on request.

\section{Declarations}

\section{Ethics approval and consent to participate}

The survey was conducted in line with the research ethics policy of the Corvinus University of Budapest. The respondents had been informed about features, data protection and ethical considerations of the research.

\section{Consent for publication}

NA.

\section{Competing interests}

The authors declare that they have no competing interests to declare.

\section{Author details}

${ }^{1}$ Centre for Social Sciences, Eötvös Loránd Research Network, Centre of Excellence of the Hungarian Academy of Sciences, Tóth Kálmán u. 4, Budapest 1097, Hungary. ${ }^{2}$ Department of Sociology and Social Policy, Corvinus University of Budapest, Közraktár utca 2-4, Budapest 1093, Hungary.

Received: 2 September 2020 Accepted: 15 September 2021

Published online: 03 November 2021

\section{References}

Avolio, B. J., \& Bass, B. M. (1990). Transformational leadership development: Manual for the Multifactor Leadership Questionnaire. Consulting Psychologist Press.

Avolio, B. J., \& Bass, B. M. (1995'). Multifactor Leadership Questionnaire TM instrument (leader and rater form) and scoring guide (Form 5X-Short). Mind Garden, Inc. www.mindgarden.com

Avolio, B. J., Bass, B. M., \& Jung, D. (1996). Construct validation of the Multifactor Leadership Questionnaire. MLQ-Form 5X. xCLS Report 96-1.

Avolio, B. J., Bass, B. M., \& Jung, D. I. (1999). Re-examining the components of transformational and transactional leadership using the Multifactor Leadership Questionnaire. Journal of Occupational and Organizational Psychology, 72, 441-462.

Bass, B. M. (1985). Leadership: Good, better, best. Organizational Dynamics, 13(3), 26-40. https://doi.org/10.1016/00902616(85) $90028-2$

Bass, B., \& Avolio, B. (2004). Multifactor Leadership Questionnaire Manual (third edition). Mind Garden, Inc.

Billig, M. (2015). Kurt Lewin's leadership studies and his legacy to social psychology: Is there nothing as practical as a good theory? Journal for the Theory of Social Behaviour, 45(4), 440-460.

Boda, Zs. (2013). Politikai vezetés és kollektív cselekvés (Political leadership and collective action). Politikatudományi Szemle, 22(2), 73-89.

Bryman, A. (1996). Leadership in organizations. In S. R. Clegg (Ed.), Handbook of organization studies (pp. 276-292). Sage.

Burns, J. M. (1978). Leadership. Harper and Row.

Chancy, S. (2017). The Multifactor Leadership Questionnaire (MLQ) as a determinant measure of leadership style. Retrieved May 5, 2019, from http://ascenditur.no/blog/2017/04/16/mlq-measure-leadership-style/

Dzomonda, O., Fatoki, O., \& Oni, O. (2017). The impact of leadership styles on the entrepreneurial orientation of small and medium enterprises in South Africa. Journal of Economics and Behavioral Studies, 9(2), 104-113.

Edwards, G., \& Gill, R. (2012). Transformational leadership across hierarchical levels in UK manufacturing organizations. University of the West of England.

Etzioni, A. (1987). Entrepreneurship, adaptation and legitimation. A macro-behavioural perspective. Journal of Economic Behaviour and Organization, 8, 175-189.

Filep, R. (2018). Vezetési stílus vizsgálata MLQ segítségével a szabolcs-szatmár-bereg megyei kisvállalkozások körében (Reviewing leadership styles with MLQ in small businesses of Szabolcs-Szatmár-Bereg County). International Journal of Engineering and Management Sciences, 3(4), 36-47.

Fitzsimmons, J., \& Evans, D. J. (2005). Entrepreneurial attitudes and entrepreneurial intentions: A cross-cultural study of potential entrepreneurs in India, China, Thailand and Australia. Babson-Kauffmann Conference paper, Wellesley, MA.

Gregor, M. A., \& O'Brien, K. M. (2016). Understanding career aspirations among young women: Improving instrumentation. Journal of Career Assessment, 24(3), 559-572.

Gubik, SA. (2015). Understanding career aspirations of Hungarian students. In S. A. Gubik, \& K. Wach (Eds.), Institutional aspects of entrepreneurship (pp. 131-150). University of Miskolc.

Gubik, S. A., \& Farkas, Sz. (2016). A karriermotívumok változásának hatásai a magyarországi hallgatók vállalkozásindítási elképzeléseinek alakulására (The effects of changes in career motives on business start-up ideas of Hungarian students). Vezetéstudomány, 47(3), 46-55.

Gubik, S. A., \& Farkas, Sz. (2017). Entrepreneurship intentions and activity of students in Hungary. Global University Entrepreneurial Spirit Student's Survey 2016. National Report. W.p., Budapest Business School University of Applied SciencesUniversity of Miskolc.

Hofmeister, Á., Kopfer-Rácz, K., \& Sas, D. (2015). A magyar kis-és közepes vállalkozások vezetőinek vállalkozói hajlandósága (Entrepreneurial inclination of leaders of Hungarian small and medium-sized entreprises). Vezetéstudomány, 46(7), $41-51$. 
Inglehart, R. (1970). Cognitive Mobilization and European Identity. Comparative Politics, 3(1), 45-70. https://doi.org/10. $2307 / 421501$

Imreh-Tóth, M., Bajmócy, Z., \& Imreh, Sz. (2013). Vállalkozó hallgatók, Valóban reális jövőkép a vállalkozóvá válás? (Entrepreneur students. Is entrepreneurship a realistic vision?) Vezetéstudomány, 44(7-8), 51-63.

Kelloway, E. K., Barling, J., \& Helleur, J. (2000). Enhancing transformational leadership: The roles of training and feedback. Leadership \& Organization Development Journal, 21(3), 145-149.

Koltai, J. P., \& Szalka, É. (2013). A vállalkozói hajlandóság vizsgálata a női hallgatók körében Magyarországon (Reviewing entrepreneurial inclination among female students in Hungary). Vezetéstudomány, 44(7-8), 71-97.

Krueger, N. F., \& Brazeal, D. V. (1994). Entrepreneurial Potential \& Potential Entrepreneurs. Entrepreneurship Theory and Practice, 18(3), https://doi.org/10.14211/regepe.v7i2.1071.

Kuczi, T., \& Lengyel, Gy. (2001). The spread of entrepreneurship in Eastern Europe. In P. Meusberger \& H. Jöns (Eds.), Transformations in Hungary (pp. 157-172). Essays in Economy and Society.

Kuczi, T., Lengyel, Gy., Nagy, B., \& Vajda, Á. (1991). Entrepreneurs and potential entrepreneurs. The chances of getting independent. Society and Economy (No.2. pp. 134-150).

Lengyel, Gy. (Ed.). (1996). Vállalkozók és vállalkozói hajlandóság (Entrepreneurs and entrepreneurial inclination). BKE.

Lengyel, Gy. (2008). A vállalkozói hajlandóság hatása a vállalkozásra és a jólétre. A Magyar Háztartás Panel néhány tanulsága (1992-2007) (Effects of entrepreneurial inclination on entrepreneurship and well-being. some lessons of the Hungarian Household Panel). In T. Kolosi, \& I. Gy. Tóth (Eds.), Társadalmi riport 2008 (pp. 429-450). Tárki.

Lengyel, Gy. (2009). Entrepreneurial inclination, potential entrepreneurs and risk avoidance. In I. Gy. Tóth (Eds.), Tárki European Social Report 2009 (pp. 115-132). Tárki.

Lengyel, Gy., \& Róna-Tas, Á. (1997). Entrepreneurship in Eastern Europe I. International Journal of Sociology, 27(3), 3-14.

Likert, R. (1967). The human organization: Its management and values. McGraw-Hill.

Lowe, K. B., Kroeck, K. G., \& Sivasubramaniam, N. (1996). Effectiveness correlates of transformational and transactional leadership: A meta-analytic review of the MLQ literature. The Leadership Quarterly, 7, 385-425.

Mészáros, J. (2011). Numerikus módszerek (Numeric Methods). Digitális Tankönyvtár, Miskolci Egyetem Földtudományi Kar, GEMAK 6841B.

Öncer, A. Z. (2013). Investigation of the effects of transactional and transformational leadership on entrepreneurial orientation. International Journal of Business and Social Research, 3(4), 153-166.

Petheő, A. I. (2013). Hallgatói vállalkozási tervek vizsgálata a GUESSS 2011-es felmérés alapján (Investigating entrepreneurial plans of students based on the 2011 GUESSS survey). Vezetéstudomány, 44(7-8), 64-70.

Radaev, V. (1997). Practicing and potential entrepreneurs in Russia. In: Lengyel, Gy., Róna-Tas Á. (eds.). Entrepreneurship in eastern Europe I. International Journal of Sociology, 27(3), 15-50.

Rauch, A., Wiklund, J., Lumpkin, G. T., \& Frese, M. (2009). Entrepreneurial orientation and business performance: An assessment of past research and suggestions for the future. Entrepreneurship Theory and Practice, 33(3), 761-787.

Reisinger, A. (2013). Családi vállalkozás folytatásának tervei a felsőoktatási hallgatók körében (Plans to continue a family business among students of higher education). Vezetéstudomány, 44(7-8), 41-50.

Shapero, A., \& Sokol, L. (1982). The social dimensions of entrepreneurship. In C. A. Kent, D. L. Sexton, \& K. H. Vesper (Eds.), The encyclopedia of entrepreneurship (pp. 72-90). Prentice Hall.

Sheppard, L. D. (2018). Gender differences in leadership aspirations and job and life attribute preferences among U.S. undergraduate students. Sex Roles, 79(9-10), 565-577.

Stafford, M. (2010). The full range leadership model: A brief primer. Jeanne M. Holm Center.

Szerb, L., \& Lukovszki, L. (2013) Magyar egyetemi hallgatók vállalkozási attitűdjei és az attitűdöket befolyásoló tényezők elemzése a GUESSS-felmérés adatai alapján—Kik is akarnak ténylegesen vállalkozni? (Analysis of the entrepreneurial attitudes of Hungarian University students and the factors influencing the attitudes based on the data of the GUESSS survey - who actually want to be entrepreneurs?). Vezetéstudomány, 4(7-8), 30-40.

Temesi, M. (2014). A hallgatók vállalkozási hajlandóságának és az azt befolyásoló tényezők vizsgálata Magyarországon (Reviewing students' entrepreneurial inclination and the factors influencing it in Hungary). E-conom, 3(1), 25-39.

Zaal, S. (2017). Differences in leadership styles between genders: Outcomes and effectiveness on team success. Ed.D. Dissertations.

\section{Publisher's Note}

Springer Nature remains neutral with regard to jurisdictional claims in published maps and institutional affiliations.

\section{Submit your manuscript to a SpringerOpen ${ }^{\circ}$ journal and benefit from:}

- Convenient online submission

Rigorous peer review

- Open access: articles freely available online

- High visibility within the field

- Retaining the copyright to your article

Submit your next manuscript at $\boldsymbol{\Delta}$ springeropen.com 